\title{
Kill the hen that crows like a cock: animal encounters in Old Yiddish
}

\author{
I R I S I E L S O N - S H E I N
}

BEN-GURION UNIVERSITY OF THE NEGEV, ISRAEL

\begin{abstract}
AвSTRACT This article focuses on a selection of Yiddish adaptations of well-known European tales, which were produced during the seventeenth and eighteenth centuries. It examines the ways in which these Old Yiddish tales express concerns surrounding Jewish life in Diaspora, by envisioning strange encounters between humans and animals. The article attempts to untangle the complex discursive web of which these animal-encounter tales formed a part, and which connected notions of humanity and animality with those of religion, gender and class. I argue that in their depictions of aberrant animality, these tales drew on the identification of Jews and animals, as well as on the relationship between animals and violence, to grapple with the dialectical relationship between Yiddish literature and its adjacent Hebrew and German libraries.
\end{abstract}

W HEN YIDDish Literature began to develop, sometime during the late Middle Ages, it found only a marginal space in which to thrive. Traditional forms of Jewish writing were already monopolized by loshn koydesh (Hebrew-Aramaic). ${ }^{1}$ And yet, somehow, within this space, there grew an immense body of works, ranging from quasi-secular genres - such as lyric, drama, fables and scientific works - to Bible translations, ethical works, tkhines (Yiddish prayers for women) and more. Over the centuries, Yiddish emerged as the language of novel forms of writing, of new genres, new readerships, new kinds of authors and printers, new modes of expression. Its

This project has received funding from the European Research Council (ERC) under the European Union's Horizon 2020 research and innovation programme (grant agreement No. 80186I). I am grateful to Amir Engel, Ahuvia Goren, Yakov Z. Mayer and the anonymous reader for the Journal of Jewish Studies for their salient comments on earlier drafts of this article. Warm thanks also to David Sclar and Oren Roman for their valuable advice and support.

I. On the division of labour between Hebrew and Yiddish, see Chone Shmeruk, Sifrut Yiddish: prakim le-toldoteha (Tel Aviv: Porter Institute, 1978); Shlomo Berger, 'Functioning within a Diasporic Third Space: The Case of Early Modern Yiddish', Jewish Studies Quarterly I5:I (2008), pp. 68-86.

JOURNAL OF JEWISH STUDIES | vOL. LXXI NO. 2 | AUTUMN 2020 | pp. 32I-44 | ISSN O022-2097| https://doi.org/Io.I8647/3462/JJs-2020 | https://orcid.org/oooo-00oI-9809-5228 | COPYRIGHT @ Oxford Centre for Hebrew and Jewish Studies, 2020.

○ Open access article under C C-B Y-N C-ND licence, freely available from the $J J S$ website. 
unique, often uneasy position - between old and new, German and Hebrew, high and low, Christian and Jewish, women and men - made Old Yiddish literature a corpus of change, and invited a preoccupation with liminality and transformation between its pages.

The present article tackles this fascination with transformation, as it appears in a selection of Old Yiddish adaptations of well-known European (non-Jewish) tales. In my reading of these tales, I examine the ways in which Yiddish narrators expressed their fantasies and concerns surrounding Jewish life in Diaspora, by envisioning strange encounters between humans and animals. I attempt to untangle the complex discursive web of which these animal-encounter tales formed a part, and which connected notions of humanity and animality with those of religion, gender and class. I argue that in their depictions of aberrant animality, these tales drew on the identification of Jews and animals, as well as on the relationship between animals and violence, to grapple with the dialectical relationship between Yiddish literature and its adjacent Hebrew and German libraries.

\section{'A wondrous and very useful nice tale'}

The story with which this article is primarily preoccupied appeared in a small, II-page booklet bearing the (conventional) title Ayn vunderlikh unt zer nutslikh sheyn mayse (A Wondrous and Very Useful Nice Tale). The booklet, which survives in only one copy, kept by the Bodleian Library in Oxford, was published sometime during the early eighteenth century, probably in Offenbach, near Frankfurt am Main. ${ }^{2}$ It tells of King Hyrcanus of Jerusalem, who had seven sons and a daughter, who was born with a golden star on her forehead (ayn gilden shternkhen an der shtirn). ${ }^{3}$ One day, the girl falls ill, and her brothers are sent to fetch her a pitcher of water from a nearby well. On their way back home the brothers begin to quarrel and they accidentally drop the pitcher. In response, their mother angrily exclaims: 'A curse on you!

2. Ayn sheyn mayse, Oxford, Bodleian, Opp. $8^{\circ}$ II I2 I. On the book's date and place of publication, see Sarah Zfatman, 'The Tale of Hyrcanus' Seven Sons Who Were Transformed into Geese - On the Yiddish Adaptations of an International Folktale (AT 45I)', Mechkare Yerushalayim be-folklor Yehudy Io (1987/8), p. 38 (in Hebrew); Moritz Steinschneider, Catalogus librorum hebraeorum in bibliotheca Bodleiana (Berlin, I852-60), p. 6i5 \$3909.

3. Ayn sheyn mayse, $2 \mathrm{r}$. 
I hope I never see any of you again!' No sooner are these words uttered than the boys turn into geese and fly away into the forest. A few years go by, and their sister sets out to find them. After much wandering she discovers that in order to reverse the curse she must remain mute for seven years. She accepts the challenge and continues to wander silently through the forest, until she is discovered by a neighbouring king, by the name of Aristobulus. The king immediately recognizes the silent beauty's nobility, falls in love with her, and marries her. Aristobulus's mother, however, is far less enamoured with her new, and soon-pregnant, daughter-in-law, and she attempts to cast doubts not only on her nobility but also on her humanity, referring to her as a vild tir - a wild animal. ${ }^{4}$

One day, while Aristobulus is away on a business trip, the princess goes into labour, and she gives birth to twin boys, each with a golden star on his forehead. Her evil mother-in-law has a servant kidnap the infants, and abandon them in the desert, where they encounter a hungry lioness. The lioness pounces on the children; however, upon identifying that they are descended from a high and noble royal creed (hokhn edel kiniglikhn shtam), she decides to adopt rather than devour them. ${ }^{5}$ Back at the palace, the evil queen mother replaces the infants with two newborn puppies. Returning from his travels, Aristobulus discovers the purported monstrous birth, and he reluctantly sentences his wife to be burned at the stake. The princess accepts her dismal fate and resigns to die in silence. Luckily, however, the day of the execution coincides with the end of her era of silence, and she is delivered by the appearance of her now-human brothers, accompanied by her two real sons. Having learned the true identity of his virtuous wife, and the true nature of his conniving mother, Aristobulus orders that his mother, 'the old cursed beast' (di alte fer flukhte bestie), be burned at the stake instead of his wife. ${ }^{6}$

4. Ayn sheyn mayse, 5r. A transliteration of the tale is offered in Zfatman, 'Ma'aseh', pp. 83-93. A liberal and truncated English translation is offered in Joachin Neugroschel, No Star Too Beautiful: Yiddish Stories from 1382 to the Present (New York and London: W.W. Norton, 2002), pp. 83-91.

5. Ayn sheyn mayse, $5 \mathrm{r}$.

6. Ayn sheyn mayse, 5v. 


\section{Translation and transformation}

As Sarah Zfatman has shown, the Yiddish tale constitutes a heavily Judaized version of the international tale of the princess and her bewitched brothers, of which there exist several written versions, primarily in German. ${ }^{7}$ Of course, none of these versions makes any mention of Jerusalem or its Jewish kings these and other elements of the tale were introduced by the Yiddish narrator to mould the non-Jewish source text into a seemingly 'kosher' Jewish work. This kind of domestication or Judaization of foreign texts was a ubiquitous strategy among both Yiddish and Hebrew writers during the early modern period. In adapting non-Jewish material for a Jewish readership, the authors of Old Yiddish transcriptions of German texts, for instance, tended to omit or to intentionally mistranslate any mention of Christian rituals, places of worship, clerics and so on. ${ }^{8}$ And yet the kind of domestication found in the tale of the Princess and the Geese goes far beyond such occasional omissions and mistranslations. Peppering his text with biblical kings, Jewish holidays, rituals, traditions and holy sites, the Yiddish narrator skilfully creates a Jewish narrative universe, and a seemingly authentic Jewish tale, which bears messages that would only have been meaningful to a Jewish readership.

In addition to the intense Judaization of the setting of the tale, numerous narrative elements were introduced to the text, for which we find no equivalent in the non-Jewish versions of the tale known to us. Many of these additions have been skilfully charted by Zfatman, who concludes that 'the amount and, more importantly, the quality of the deviations do not allow

7. Several versions of these are recorded in Wilhelm and Jacob Grimm, 'Die zwölf Brüder', 'Die drei Raben', 'Die sechs Schwäne', in Kinder- und Hausmärchen, vol. I (Berlin, I8I2), pp. 24-30, I IO-I2, 220-2I; 'Die sieben Raben', in Kinder- und Hausmärchen, 6th edn (Göttingen, I850), p. I58. As Zfatman notes, the closest version is the Bohemian-German version recorded in Johannes Bolte and Georg Polivka, Anmerkungen zu den Kinder- und Hausmärchen der Brüder Grimm (5 vols; Leipzig: Dieterich, I9I3), vol. I, pp. 428-30; https://de.wikisource.org/wiki/Seite:Grimms_M\%C3\%A4rchen_Anmerkungen_(Bolte_Polivka)_I_429.jpg (accessed 7 November 2018).

8. Compare, for instance, Ein kurtzweilig lesen von Dyl Ulenspiegel, facsimile of the I5 I5 edn (Leipzig, I9гі), 3a, І3а, 96b-97a, I15a-b, I17a-b, г26a-I27a; Eyln shpigl (Prague, I735), [I], [3], [I1], [I5]-[I6], [I8]-[19], [31]-[32]; 'Eyln shpigl', MS Munich, Cod.Hebr.Ioo, Bavarian State Library, fol.I88b, https://tinyurl.com/ybj4hpf5 (accessed 8 July 2020). For a discussion of the phenomenon, and further examples, see Arnold Paucker, 'The Yiddish Versions of the German Volksbuch', (M.A. thesis, University of Nottingham, I959), esp. pp. 22-36, 52-8, I24-45, I69-8I, 200-213, 235-46; Elisheva Carlebach, Palaces of Time: Jewish Calendar and Culture in Early Modern Europe (Cambridge MA: Belknap Press of Harvard University Press, 20II), pp. I2I-30; Ruth von Bernuth, 'Das jischev fun Nar-husen: Jiddische Narrenliteratur und judische Narrenkultur', Aschenas 25:I (2015), pp. I38-9; Iris Idelson-Shein, 'Meditations on a Monkey Face: Monsters, Transgressed Boundaries, and Contested Hierarchies in a Yiddish Eulenspiegel', Jewish Quarterly Review I08: I (2018), pp. 28-59. 
us to view the tale as part of the Yiddish corpus of mere transliterations, but rather prompt us to include it within the framework of original Yiddish prose.' ${ }^{9}$ While the sharp distinction between translation and original prose seems ill fitting for this period, Zfatman is correct in observing that the narrator of the tale of the Princess and the Geese demonstrates an exceptional investment in his adaptation of the story. ${ }^{10} \mathrm{Zfatman}$ goes so far as to suggest that the tale 'is the first story in Yiddish in which we do not find a great degree of faithfulness to the source text'. ${ }^{11}$ However, there exist several earlier Yiddish tales which take similar liberties in treating their source texts, such as the tale of the Pious Jew and his 'savage' wife, which appears in the late-seventeenth-century memoirs of Glikl bas Leib, as well as in the seventeenth-century Yiddish manuscript Be'er sheva by Bela and Ber Perlhefter of Prague, ${ }^{12}$ and the tale of the Rabbi-Werewolf, which appears in the seventeenth-century Mayse bukh, and in a second contemporary manuscript. ${ }^{13}$ I discuss both tales in some detail below; here, suffice to note that Yiddish translations/adaptations such as these share an ambivalent attitude towards their non-Jewish hypotexts - and, one may perhaps argue, towards Christian society more generally. They draw heavily on Christian text and narrative traditions, but at the same time attempt to keep the non-Jewish element of their works at bay. Unlike contemporary near-transliterations of non-Jewish

9. Zfatman, 'Ma'ase', p. 35. For a comparative reading of the tale vis-à-vis the German versions recorded by the Brothers Grimm, see ibid., pp. 47-77.

Io. On notions of originality, imitation and translation in the early modern period, see Peter Burke, 'Cultures of Translation in Early Modern Europe', in Peter Burke and R. Po-Chia Hsia (eds), Cultures of Translation in Early Modern Europe (Cambridge: Cambridge University Press, 2007), pp. 26-35; Marilyn Randall, Pragmatic Plagiarism: Authorship, Profit, and Power (Toronto: University of Toronto Press, 200I), pp. 197-2I7.

II. Zfatman, 'Ma'ase', p. 35 .

I2. Zikhronot Glikl, 1691-1719 (bilingual edn) (trans. Chava Turniansky; Jerusalem: Zalman Shazar Center for Jewish History, 2006), pp. 80-106; Bela and Baer Perlhefter, 'Beer sheva', Paris Alliance Israelite Universelle, MS. no. 295, photocopy at National Library Israel [NLI], reel no. F330I, fol. 9r. Critical edition by Nathanael Riemer and Sigrid Senkbeil (eds), Be'er Sheva by Beer and Bella Perlhefter: An Edition of a Seventeenth Century Yiddish Encyclopedia (Wiesbaden: Harrassowitz, 2011), pp. 40-43. On the tale's relationship with its putative source, see Natalie Zemon Davis, Women on the Margins: Three Seventeenth-Century Lives (Cambridge MA: Harvard University Press, I995), pp. 40-I, 245 nn. I38-9; Idelson-Shein, " "What have I to do with Wild Animals?”: Glikl Bas Leib and Other Women', Eighteenth-Century Studies 44:I (2010), pp. 57-77.

I3. Oxford, Bodleian, MS. Opp. 7I4, fols 9r-I8r; Mayse bukh (I602. repr. Frankfurt, I702), IIorII3r. For a comparative reading of the source and target texts, see Astrid Lembke, 'Das unwillige Untier. Ehe, Gefolgschaft und Autonomie in den französischen und jiddischen Werwolferzählungen Maries de France (I2. Jh.) und im Mayse-Bukh (I602)', Germanisch-Romanische Monatsschrift 68 (2018), pp. I-26. 
works - in which Judaization serves primarily polemical or comical purposes ${ }^{14}$ - works such as the tale of the Princess and the Geese view their non-Jewish hypotexts as an invitation to create a new, pointedly Jewish, work. Employing a range of literary techniques, they domesticate their tales, allowing them to blend almost seamlessly into a purportedly authentic 'Jewish library', where they may perch alongside similarly domesticated Hebrew translations. Such intense Judaization necessarily requires a high degree of attentiveness to narrative, making any additions, omissions and other departures from the source text particularly worthy of our attention.

\section{What's in a name? The early modern Esther and her biblical namesake}

In the story of the Princess and the Geese, the process of Judaization begins already in the text's opening lines, which locate the tale in Jerusalem, during the reign of King Hyrcanus of the Hasmonean dynasty. ${ }^{15}$ As Zfatman has shown, the Second Temple setting is further reinforced throughout the story, through the mention of certain figure and place names, such as Aristobulus; the Kidron River crossed by the protagonist upon leaving Jerusalem; the city of Rome, to where Aristobulus wanders; and the Temple itself, where the princess learns of her brothers' unhappy fate. ${ }^{16}$ But of all the names used by the narrator, one stands out - the only female name in the tale - that of the silent princess.

Having completed her silent quest successfully, the princess is approached by her husband, Aristobulus, who asks: 'are you Esther?' (biztu es Ester?). The discovery of the silent princess's true identity is rattling not only for the king, but also for the reader. Indeed, it is only here, towards the very end of the story, that the princess's name is revealed. This stands in striking contrast to all other characters in the tale, who are either identified by name upon first mention or not at all.

Zfatman argues that the choice of geographical and temporal setting in the tale of the Princess and the Geese, as well as the choice of names for

\footnotetext{
I4. Paucker, 'Yiddish Versions', p. 3.

I5. King Hyrcanus appears as a protagonist also in the tale of 'Beryo und Zimero'. See MS Munich, Cod.Hebr.Ioo, Bavarian State Library, fol. 67a; https://tinyurl.com/yd6b3y3r. The name also appears in a negative context in the Mayse bukh.

16. Zfatman, 'Ma'ase', p. 54.
} 
the story's protagonists, bear little significance to the overall meaning of the tale. These narrative choices, she suggests, are designed merely to Judaize the text and to give it an air of historical accuracy. ${ }^{17}$ But if historical accuracy is, indeed, the guiding principle behind the selection of names in the tale, the choice of the name 'Esther' appears jarring. Unlike the names of the two kings, which fit neatly into the Second Temple setting, the name Esther is an exilic name, which situates the story no longer in Second Temple Jerusalem but in Persia. The exilic nature of the name is reinforced by the fact that - in contrast to Aristobulus and Hyrcanus - Esther was a popular name among central-European Jews during the early modern period. ${ }^{18}$ The name thus ties the story not to Jerusalem, but to exile, unsettling the Second Temple setting that the author seems to have worked so hard to establish. Indeed, by invoking the name, the Yiddish author, at one and the same time, pushes the narrative back into fifth-century в се Persia, and pulls it forward into his contemporary Ashkenaz. Understood in this light, the postponement of the revelation of the name to the end of the story begins to make sense, as it throws all prior attempts at historical accuracy throughout the narrative in an almost comical light.

But what, we may ask, is in a name? Could this historical inconsistency be the result of mere narratorial oversight? This seems unlikely. As noted above, the narrator of the tale of the Princess and the Geese demonstrates an unusual degree of attentiveness, making such inconsistencies particularly meaningful. In fact, in choosing the name Esther for his protagonist, and in keeping the revelation of the name to the end of the story, the narrator seems to demonstrate not only a high level of authorial sophistication (perhaps irony), but also an expectation that his readers share this level of sophistication. ${ }^{19}$ Indeed, the main protagonist's name ties together several distinct threads which intertwine throughout the tale. First, and perhaps most evidently, the name would have appealed to the narrator because of its assonance with the Yiddish/German word shtern/Stern - star - referencing

I7. Ibid., pp. 57-9.

I8. A restricted search for the years I690-I750 in the EPIDAT database, which collects tombstone inscriptions from Jewish cemeteries around Europe, yields 40 hits for the name Esther, second only to Sarah, which appears on 68, and Rivkah, which appears 42 times. See www.steinheim-institut. de/cgi-bin/epidat?lang=de (accessed 8 November 2018).

I9. For more on the interpretative competencies of the readers of Old Yiddish literature, see Jeremy Dauber, In the Demon's Bedroom: Yiddish Literature and the Early Modern (New Haven CT: Yale University Press, 2010), esp. pp. I8-35, I63-4. 
the golden star inscribed onto the princess's flesh, as well as to the word designating forehead, shtirn/Stirn. The name furthermore seems to echo the princess's mysterious origins in the eyes of her husband, Aristobulus, and his court. According to rabbinical interpretations of the book of Esther, originally given the Hebrew name Hadassah, Esther was granted a second name to hide her Jewish origins. Significantly, the act of hiding is not only achieved by the Persian name, but also conveyed by it; according to one interpretation, the name is derived from the Hebrew word mesateret, 'to hide'. ${ }^{20}$

But there is more to the name than mere wordplay; in fact, corollaries between the Yiddish Esther and the biblical Esther are striking. Like the biblical Esther, the early modern Esther is chosen to be queen for her beauty; like her ancient namesake, she too is wed to a somewhat gullible king, keeps her true identity concealed, and must deal with courtly conspiracies and forces striving to obliterate her. And yet reading the image of the Yiddish Esther against that of her biblical namesake also reveals some striking differences, which illuminate the particular early modern context of the Yiddish tale. Let us recall how the biblical Esther is asked by Mordecai to liaise for the Jews with her husband, King Ahasuerus. Reluctant at first to approach the king, Esther is convinced to speak up for her people by Mordecai, in what is perhaps one of the most familiar biblical admonitions:

if you remain silent at this time, relief and deliverance for the Jews will arise from another place, but you and your father's family will perish. And who knows but that you have come to your royal position for such a time as this? (Esther 4:I3-I4)

The difference between the two Esthers could not be more pronounced; while the biblical Esther saves the Jewish people by courageously speaking, the early modern Esther saves her brothers - and is subsequently delivered from death at the king's hands - by remaining silent. ${ }^{21}$ It is thus silence, not speech, that is marked as the ultimate feminine virtue in the tale of the Princess and the Geese.

20. bMeg. г3a.

2I. Emily Colbert-Cairns argues that in early modern Spain Esther's image became that of 'a silent ornament to be admired'. See Emily Colbert-Cairns, 'Esther Among Cryto-Jews and Christians: Queen Esther and the Inquisition Manuscripts of Isabel de Carvajal and Lope de Vega's La Hermosa Ester', Chasqui 42:I (2013), p. Io6. 
In its emphasis on feminine silence, the tale echoes contemporary anxieties surrounding women and words. Of course, such concerns have been around for centuries, and linger to this very day. And yet, as several studies have shown, the early modern period saw an exponential increase in these fears, as the venomous tongues of women became the focus of intense literary, artistic and even criminal scrutiny. ${ }^{22}$ These concerns were no less poignant among early modern Jews. Significantly, they seem to arise with an added urgency in works written in Old Yiddish, which granted Jewish women unprecedented access to the written word. A seventeenth-century Yiddish song (lid) from Prague, for instance, informs us that gossip and evil speech are the greatest of all sins, and warns: 'women must be guided / they have stemmed from Eve / who spoke falsely to her man / and man was expelled / from the Garden of Eden. ${ }^{23}$ A reminiscent though slightly different accusation appears in the so-called Yiddish 'women's Bible', the Tsene u-rene. This time it is not Eve's conversation with Adam that is the root of all evil, but rather her conversation with the serpent. The name Eve, we are informed, means 'to talk, [for] she should not have talked so much with the serpent'. ${ }^{24}$ These and other such representations of Eve's speech acts as the original original sin offer an indication of just how troubling women's words were for early modern authors.

The hazardous effects of feminine speech are painfully evident in the tale of the Princess and Geese. The tale depicts three women, all of whom share a problematic relationship with words. The evil mother-in-law represents the age-old figure of the devious, serpentine woman, whose toxic tongue unleashes havoc and lies. Esther's mother, on the other hand, is depicted in the likeness of the Tsene u-rene's Eve, whose unruly speech brings about disaster and expulsion; Esther's seven brothers are transformed into geese by their mother's scolding, and must flee the Holy Land to live out their lives

22. See, e.g., Ralf Georg Bogner, Die Bezähmung der Zunge: Literatur und Disziplinierung der Alltagskommunikation in der frühen Neuzeit (Tübingen: Niemeyer, 1997); Claudia Benthien, 'Zwiespältige Zungen. Der Kampf um Lust und Macht im oralen Raum', in Claudia Benthien and Christoph Wulf (eds), Körperteile: Eine kulturelle Anatomie (Reinbek bei Hamburg: Rowoht Taschenbuch Verlag, 200I), pp. II I-I6; Christina Luckyj, 'A Moving Rhetoricke': Gender and Silence in Early Modern England (Manchester: Manchester University Press, 2002); Lynda Boose, 'Scolding Brides and Bridling Scolds: Taming the Woman's Unruly Member', Shakespeare Quarterly 42:2 (I99I), pp. I84-5.

23. Devra Kay, Seyder Tkhines: The Forgotten Book of Common Prayer for Jewish Women (Philadelphia PA: Jewish Publication Society, 200I), p. 234.

24. Jacob ben Isaac Ashkenazi of Yanow, Tsene u-rene (Sulzbach, I692), 5v. 
as forest animals. ${ }^{25}$ It seems only adequate, then, that to reverse the curse requires seven years of feminine silence.

\section{Purim plays and monstrous births: political signposts in the tale of the Princess and the Geese}

Esther's silence communicates not only the narrator's understanding of adequate femininity, but also an intriguing position on the proper response to persecution more generally. Here again, Esther's name may hold the key to hidden meanings within the tale. As Elliott Horowitz has shown in a now classic study, the invocation of the book of Esther in different literary and historical contexts often bears distinct political undertones. ${ }^{26}$ This holds particularly true in the context of the seventeenth- and eighteenth-century Yiddish-speaking world, where Purimplays (Purim sphiln) - particularly those based on the book of Esther - were wildly popular, with their comic dramatization of Jewish persecution, resistance and revenge. As Jerold Frakes has recently commented:

Purim plays based on the Esther narrative ... are by definition a symbolic insurrection. The entire story is not just open to contemporary politicizing by any given playwright in any given period, it is in fact so overtly and volatilely political that a playwright would have to shun the topic altogether in order to avoid political engagement on some level. ${ }^{27}$

Frakes's presentation of the inevitable politicization of the book of Esther may be slightly exaggerated, but it prompts us to investigate the possibility that the protagonist's name may function as a kind of political signpost in the tale of the Princess and the Geese, signalling to the reader that there is a deeper message to be taken from the tale, one that deals precisely with the questions of persecution and salvation to which the book of Esther is so closely tied. This hypothesis seems to be supported by the episode of Esther's purported monstrous birth, or the 'puppy libel', as it were. Monstrous births were a hot topic in early modern Europe, and, like the Purim shpiln, were

25. One is reminded here, perhaps, of the German term Schnattergans ('chattering goose'), used to refer to a talkative woman.

26. Elliott Horowitz, Reckless Rites: Purim and the Legacy of Jewish Violence (Princeton NJ: Princeton University Press, 2006).

27. Jerold C. Frakes, The Emergence of Early Yiddish Literature: Cultural Translation in Ashkenaz (Bloomington IN: Indiana University Press, 20I7), p. 98. 
often harnessed for distinct political purposes. ${ }^{28}$ Particularly interesting for our purposes is the use of the monstrous birth in early modern Judeophobic rhetoric. A case in point is a broadsheet written by the German author Johann Fischart. Published in 1575, the broadsheet describes the alleged birth of twin piglets to a Jewish woman in Binswangen. Fischart saw the birth as conclusive evidence that the Jews had erred in their rejection of Christ. ${ }^{29}$ Similar explanations were provided by other authors to explain the births of Jewish pigs, chickens and conjoined twins. ${ }^{30}$

Returning to the tale of the Princess and the Geese, Esther's purported 'monstrous birth' may, perhaps, be read as a shrewd reference precisely to such anti-Jewish rhetoric. The episode taps on the ubiquitous association, which existed in European imagination, not only between Jews and monsters, but also between Jews and dogs. ${ }^{31}$ Admittedly, the scene in which the evil mother-in-law replaces the infants with puppies originates in the non-Jewish versions of the tale. ${ }^{32}$ However, the Yiddish narrator takes extra care in adapting this scene, adding another, particularly suggestive scene, in which Esther is brought to the stake with the two dogs hanging on either side of her. This narrative component appears in none of the other versions of the tale known to me, and it seems safe to assume that it is the Yiddish narrator's original addition.

Here, once again, a return to the image of the biblical Esther offers a way of approaching the text's idiosyncrasies. Rabbinic interpretations attribute

28. See Marie-Hélène Huet, Monstrous Imagination (Cambridge MA: Harvard University Press, 1993); Mary Fissel, Vernacular Bodies: The Politics of Reproduction in Early Modern England (Oxford: Oxford University Press, 2004), pp. I58-65; Julie Crawford, Marvellous Protestantism: Monstrous Births in Post-Reformation England (Baltimore MD: Johns Hopkins University Press, 2005).

29. Robert Jütte, 'Die schwangere Jüdin von Binswangen. Ein Lehrstück christlich-jüdischer Beziehungen im Augsburger Umfeld des I6. Jahrhunderts', in Andreas Schmauder and Jan-Friedrich Mißfelder (eds), Kaftan, Kreuz und Kopftuch: Religiöse Koexistenz in urbanen Raum (Ostfildern: Thorbecke, 20Io), pp. 65-85; Debra Kaplan, Beyond Expulsion: Jews, Christians, and Reformation Strasbourg (Stanford CA: Stanford University Press, 201 I), pp. II2-I5.

30. David B. Ruderman, Kabbalah, Magic, and Science: The Cultural Universe of a Sixteenth-Century Jewish Physician (Cambridge MA: Harvard University Press, I988), pp. 74-88; Robert Jütte, 'Im Wunder vereint: eine spektakuläre Missgeburt im Ghetto I575', in U. Israel, R. Jütte and R.C. Mueller (eds), Interstizi: Culture ebraico-cristiane a Venezia e nei suoi domini dal medioevo all'età' moderna (Rome: Edizioni di Storia e litteratura, 20I0), pp. 530-39, 52I, 536-7.

3I. On this association, see Kenneth Stow, Jewish Dogs: An Image and Its Interpreters: Continuity in the Catholic-Jewish Encounter (Stanford CA: Stanford Unversity Press, 2006). See also Elliott Horowitz's critical, but complementary, 'Circumcised Dogs from Matthew to Marlowe', Prooftexts 27:3 (2007), pp. $53 \mathrm{I}-45$.

32. See, e.g., Bolte and Polívka, Anmerkungen, pp. 429, 432. 
Psalm 22:17 to Queen Esther: 'For dogs are all around me; a company of evil-doers encircle me.' One particularly interesting interpretation, by the sixteenth-century rabbi R' Samuel de Medina, has Esther reciting the psalm while envisioning herself lodged between two dogs - the king, Ahasuerus, and his adviser Hamman. ${ }^{33}$

Significantly, execution by hanging between two dogs was, during the early modern period, a traditional penalty inflicted primarily on Jews. ${ }^{34}$ While the practice had largely died out by the late seventeenth century, its memory lived on well into the eighteenth and nineteenth centuries as a particularly heinous form of anti-Jewish persecution..$^{35}$ It thus stands to reason that the scene of Esther's hanging would have resonated strongly among contemporary Yiddish readers, and that her continued silence between the dogs would have been understood as a form not only of feminine but also of Jewish virtue.

And, indeed, in Jewish literature from the Middle Ages onwards, the figure of Esther often features as a symbol of the Jewish minority in Diaspora, and particularly for Jewish perseverance in the face of persecution. It was specifically Esther's concealing of her Jewish identity, not necessarily her speech acts, with which European Jews were able to identify. Thus, for instance, as Barry Walfish explains, the Conversos, or crypto-Jews of Spain and Portugal, 'could readily identify with Esther who would not reveal her race or her birth yet remained steadfast in the religion of her forefathers

33. Samuel de Medina, Sefer ben Shmuel (Mantova/Mantua, I622), 26r. I am grateful to Ahuvia Goren for bringing these discussions to my attention.

34. Scholars have debated the exact origins of the practice and its medieval association with Jews, but there is a general agreement that by the fifteenth and sixteenth centuries it was indeed primarily a form of anti-Jewish persecution. See Rudolph Glanz, “The Jewish Execution” in Medieval Germany', Jewish Social Studies 5:I (I943), pp. 3-26; Guido Kisch, “"The Jewish Execution” in Medieval Germany', Historia Judiaca 5 (I943), pp. I03-32; Gerd Mentgen, 'Der Würfelzoll und andere antijüdische Schikanen in Mittelalter und Früher Neuzeit', Zeitschrift für historische Forschung 22:I (I995), pp. 40-46; Norbert Schnitzler, 'Von Bilderfeinden zu Glaubensfeinden. Zur Funktion eines antijüdischen Stereotyps in christlich-jüdischen Konflikten des Mittelalters', in Juliette Guilbaud, Nicolas le Moigne and Thomas Lütteberg (eds), Kulturelle Normen und Konstruktion von Devianz: Antijüdische und antisemitische Beschuldigungen in der Frühen Neuzeit und in der Moderne (Paris: École pratique des hautes études, 2004), pp. 44-7.

35. See, e.g., Voltaire, 'Essai sur les mœurs et l'esprit des nations' (I756), in CEuvres complètes de Voltaire, vol. I7 (Paris: La société littéraire-typographique, I785), p. 532; Leopold Zunz, Die synagogale Poesie des Mittelalters (Berlin: J. Springer, I855), p. 342; Johann Christian Schinke, Biblische Alterthumskunde in alphabetischer Folge (Neustadt an der Orla, I836), p. 650. See also Glanz, " "The Jewish Execution" in Medieval Germany', p. 9. 
while living in alien surroundings. ${ }^{36}$ Even for those who remained openly Jewish, Esther could serve as a model for Jewish survival in exile. As Sidnie Ann White notes, the story of Esther delivers a powerful message, according to which, "by accepting the reality of a subordinate position and learning to gain power by working within the structure rather than against it, the Jew can build a successful and fulfilling life in the Diaspora, as Esther does in the court of Ahasuerus.' ${ }^{37}$

\section{Animality and exile in Jewish literature and art}

Esther's unusual encounter with the two dogs is merely one of a series of strange human-animal encounters that occur in the tale of the Princess and the Geese. In fact, animals lurk at every turn in the tale, almost always with disastrous results. Throughout the narrative, the animal world is presented as a constant threat, which is forever encroaching on humanity from its margins, seeping into the borders of the human, often through the actions and the words of women. A mother's curse turns her children into geese; another mother substitutes her grandchildren for puppies; yet another woman is suspected of being not entirely human, and is sentenced to be burned at the stake between two dogs; human babies are raised by a lioness; and the terms vilde tir and bestie - wild animal and beast - are consistently flung at the female protagonists of the tale.

The tale is thus structured in the form of a perpetual back and forth movement between the human and the animal, as its author anxiously explores the extreme malleability of bodies and beasts. This slipperiness of species is finally resolved in the second part of the story, which offers a reversed narrative, in which the borders between the human and the animal are reconstructed, and social and familial order is restored. The brothers are transformed back into men, the children return to their human mother, Esther's humanity is finally recognized, the evil queen mother is burned at the stake, and the siblings return to Jerusalem to reunite with their parents. This restorative narrative leads into the book's closing words: 'May the Lord God, blessed

36. Barry Walfish, Esther in Medieval Garb: Jewish Interpretations of the Book of Esther in the Middle Ages (New York: State University of New York Press, 1993), p. I25. See also Colbert-Cairns, 'Esther among Crypto-Jews', pp. 98-I09.

37. Sidnie Ann White, 'Esther: A Feminine Model for Jewish Diaspora', in Peggy L. Day (ed.), Gender and Difference in Ancient Israel (Minneapolis MN: Fortress, 1989), p. I73. 
be he, soon bring also us joy and set us free, from this bitter exile, and may he soon send us the Messiah of the House of David, Amen. ${ }^{38}$

These closing lines constitute a traditionalist formula, which appeared in numerous Yiddish works from the period. ${ }^{39}$ The formulaic nature of these lines should not, however, blind us to their particular narrative significance. Indeed, the book's closing lines complement the work's content, consolidating the parallel between the story of Esther and her brothers, and the fate of the Jews in Diaspora. These messianic aspirations, so typical of their time, put the narrator's choice of the Second Temple setting in a new light, suggesting that the choice has to do not only with the need to Judaize the tale per se, but also, and perhaps more importantly, with the narrator's preoccupation with the issue of exile and return. Indeed, the use of the formula gives rise to the impression that within the story of the Princess and the Geese animality is equated with exile, and the restoration of humanity with the return of the Jews. Having been transformed into geese, the brothers fly away from their home, into exile in the woods; born in Diaspora, the two infant princes are replaced by dogs and raised by a lioness; living as a queen in a foreign land, the princess is constantly under suspicion of being a beast. For all three groups - the brothers, the princess and her sons - the recognition or re-establishment of humanity signals the end of exile and return to the Holy Land.

Animals have long featured as symbols of Jewish Diasporic existence, in both Christian and Jewish works. In European Christian imagination, from medieval and into modern times, ignoble animals such as pigs, dogs, rats, toads and scorpions were often used as analogies for the Jewish presence in Europe. These images were used to debase and ridicule Jews (as testified by the animal-birth tales and the link between Jews and dogs surveyed above), but also, as Debra Strickland has recently argued, to define 'the place of Jews and Judaism in the economy of Christian salvation. ${ }^{40}$ Significantly, animals appear as symbols of Jewish existence in Europe not only in Christian but also in Jewish works. At times such depictions were meant to lament the

38. Ayn sheyn mayse, $5 \mathrm{v}$.

39. See: Shlomo Berger, 'Invitation to Buy and Read: Paratexts of Yiddish Books in Amsterdam, I650-I80o', Book History 7 (2004), p. 38.

40. Debra Strickland, 'Monsters, Demons, and Jews in the Painting of Hieronymus Bosch', in Iris Idelson-Shein and Christian Wiese (eds), Monsters and Monstrosity in Jewish History: From the Middle Ages to Modernity (London: Bloomsbury, 2019), p. 43. 
decline of Jewish culture in Diaspora. Thus, for instance, the medieval Kabbalist Abraham Abulafia complained that Diasporic Jewry had 'exchanged their language for numerous foreign tongues, to the extent that one does not understand the other, ... almost like animals' ${ }^{41}$ Here, we find echoes of the notion, shared by numerous premodern thinkers, and alluded to also in the tale of the Princess and the Geese, that 'Man from Beast by Words is known'. ${ }^{42}$

The same notion is expressed also in Glikl's memoirs, which tell of a Pious Jew who is cast away on an East Indian island. Having spent two years among 'savage people' - to whom Glikl often refers as 'wild animals' (vilde tir) - the Jewish man becomes hirsute and begins to resemble a wild animal in every way. So dire is his condition that when a group of European sailors arrive at the island, he must convince them of his humanity by speaking 'in the manner of humans' (vi di layt redn). ${ }^{43}$ In Glikl's tale animal imagery is used not only to lament the debased state of Jews in Diaspora, but also to signify persecution in exile and subsequent deliverance with the coming of the Messiah. The story ends with the Pious Jew's reunification with his Jewish family, the establishment of a Jewish kingdom and the conversion of the Christian sailors to Judaism, signifying the Gentiles' anticipated recognition of the God of Israel in the messianic age. ${ }^{44}$ As Glikl remarks, "This is a nice tale, which offers consolation to all those sad and anxious souls, [assuring them] that one should never lose faith in the help of God, blessed be he. ${ }^{45}$

Such usage of animals to signify persecution and deliver comfort to its victims is widespread in European Jewish works through the centuries. In his study of illuminated Hebrew manuscripts, Marc Michael Epstein has revealed how medieval scribes often subverted the Christian identification of Jews with animals, and particularly with dogs, to imagine a future in which 'the pursued could triumph over their pursuers'. ${ }^{46}$ Elisheva Carlebach has shown that a similar process of reappropriation existed in early modern

4I. Quoted in Moshe Idel, “"The Time of the End”: Apocalypticism and its Spiritualization in Abraham Abulafia's Eschatology', in Albert I. Baumgarten (ed.), Apocalyptic Time (Leiden: Brill, 2000), p. 172 .

42. Alexander Pope, 'The Dunciad', in Alexander Pope: Selected Poetry and Prose (I743; repr. New York: Holt, Rhinehart and Winston, 1963), p. 43I.

43. Glikl, Memoirs, p. 92.

44. On the messianic dimensions of the tale, see Davis, Women on the Margins, p. 4I.

45. Glikl, Memoirs, p. 8o.

46. Marc Michael Epstein, Dreams of Subversion in Medieval Jewish Art and Literature (University Park PA: Pennsylvania State University Press, 1997), p. 32. 
illuminated manuscripts, and particularly in Jewish calendars, sifre evronot. According to Carlebach, the hunting scenes which were often depicted in these manuscripts, in which dogs were shown to be hunting down hares or dears, 'conveyed a subversive eschatological message to Jewish readers: that they would survive and escape the terrible pursuit by their historical foes. ${ }^{47}$

In some early modern works the empowering tone of these redemption fantasies is amplified, to create narratives focused not only on redemption but also on revenge. In formulating these fantasies, Jewish authors turned once again to what Jay Geller has aptly termed 'the Bestiarium Judaicum, that vast menagerie of verbal and visual images of nonhuman animals, real and imagined, that have been disseminated to debase, dehumanize, or justify persecution of Jews' ${ }^{48}$ Here, they found images not only of hares, dogs and deer, but also of wolves. ${ }^{49}$

\section{Fantasies of violence and narratives of restraint in Old Yiddish literature}

Particularly interesting for our purposes is another animal-transformation tale, which appears (in almost identical form) in two extant Old Yiddish sources: the hugely popular Mayse bukh (1602), and an early-seventeenthcentury collection of tales, which remains in manuscript form, and is kept at the Bodleian library. Drawing on an international tale - most famously articulated by Marie de France in her twelfth-century Bisclavret - the tale depicts a pious and learned rabbi, well-versed in all 70 tongues, who is turned into a werewolf by his conniving wife..$^{50}$ As Astrid Lembke has recently demonstrated, the Jewish version of the tale is distinct in its depiction of savage animality. Whereas earlier, non-Jewish versions stressed that the werewolf's violence is directed only at those who had caused him harm, the

47. Carlebach, Palaces of Time, pp. II2-I3.

48. Jay Geller, " "Der Volf” or The Jew as Out(side of the) law', in Idelson-Shein and Wiese (eds), Monsters and Monstrosity, p. $25 \mathrm{I}$.

49. On the identification of Jews as wolves, see ibid., p. 25I; Horowitz, 'Circumcised Dogs', p. 538.

50. Oxford, Bodleian, MS. Opp. 7I4, fols 9r-I8r; Mayse bukh, IIor-II3r. For an initial comparison of the two versions, see Jakob Meitlis, Das Ma'assebuch: Seine Entstehung und Quellengeschichte (I933; repr. Hildesheim: G. Olms, I987), pp. 93-5; 'Some Extant Jewish Folktales in Yiddish Mss.', Fabula: Zeitschrift für Erzählforschung I2 (I97I), pp. 212-I7. For an English translation, see Astrid Starck-Adler, 'Mayse-Bukh and Metamorphosis', Bulletin du Centre de recherche français à Jérusalem 8 (200I); http:// bcrfj.revues.org/2092 (accessed 23 December 2018). 
Yiddish tale depicts the rabbi-werewolf as exceedingly, and often gratuitously, ferocious, particularly (perhaps exclusively?) towards Christians. ${ }^{51}$ Following his transformation, the rabbi-werewolf, who, we read, 'is much stronger than a lion' (fil shterker az ayn leyb), ${ }^{52}$ begins to terrorize the forest, until he is finally subdued by a (non-Jewish) adviser to the king, who convinces him to spare his life by praying for God's mercy: 'Immediately the wolf let him get up [and] started wagging his tail to charm the advisor... He refused to leave him and walked by his side all the time like a dog (vi ayn hund) running in front of his master. ${ }^{53}$ Here, again, we find echoes of the Christian association of Jews with dogs, and yet, as in the tale of the Princess and the Geese, here too the association is brought forth only to be taken apart. For, indeed, while the werewolf-rabbi may appear to be a servile dog to his Christian master - wagging his tail and allowing himself to be put on a leash - he continues to maintain his (were)wolfish character, a truth of which the reader is pointedly reminded towards the end of the tale. ${ }^{54}$

Having subdued the wolf, the advisor is given the princess's hand in marriage, and subsequently becomes king. One cold winter's day, when the new king is out hunting with his wolf, the wolf inscribes a Hebrew message in the snow. Unable to understand the foreign words, the king sends for his advisors, one of whom (a Jew in the manuscript version) is finally able to decipher the message to read:

Dear King, remember the friendship I have shown towards you. I did not tear you apart when I had the upper hand... It so happens that I have a wife ... who put a spell on me using a ring and turned me into a werewolf... Go to this town and bring me back the ring which my wife has [taken], as a sign of friendship. Or else I will kill you! ${ }^{55}$

It seems significant that the rabbi insists on writing his message in the Holy Tongue, forcing the king to summon his scholars, when in fact we are told

5I. Lembke, 'Das unwillige Untier', Germanisch-Romanische Monatsschrift 68 (2018), pp. I-26; 'The Raging Rabbi: Aggression and Agency in an Early Modern Yiddish Werewolf Tale (Mayse-bukh I602)', in Idelson-Shein and Wiese (eds), Monsters and Monstrosity, pp. $20 \mathrm{I}-\mathrm{I} 2$.

52. Mayse bukh, iniv; MS. Opp. 7I4, fol. I3v.

53. Translation: Starck-Adler, 'Mayse-Bukh and Metamorphosis'; in Yiddish, see Mayse bukh, II2r; MS. Opp. 7I4, fol. I4v (with slight differences).

54. On the story's complex usage of the 'Jewish dog' imagery, see Lembke, 'The Raging Rabbi', pp. 209-Io.

55. Translation: Starck-Adler, 'Mayse-Bukh and Metamorphosis'; in Yiddish, see Mayse bukh, II2r; MS. Opp. 7I4, fol. I5r (with slight differences). 
at the beginning of the tale that he is fluent in all 70 tongues. ${ }^{56}$ Why, then, this insistence on Hebrew? Here, the analogy between animality and exile (and between exile and polyglossia) comes in handy; revealing his humanity means for the wolf revealing also his Jewishness, or, rather, insisting on it. While the language of the inscription delivers a subtle message, its content is blunt. In threatening to kill the king unless his humanity is restored to him, the wolf reveals a deep disdain for hierarchy. If animality is to be understood as a metaphor for exile in these Old Yiddish tales, the message becomes charged with contemporary meaning. And, indeed, it seems safe to imagine that the scene of a rabbi threatening to kill a king would have been a powerful one for Yiddish readers in early modern Europe.

The tale of the Princess and the Geese and the tale of the Rabbi-Werewolf share several striking similarities: both are transformation tales, in which transgressions of the human-animal divide serve as metaphors for exile; in both the animal transformation is triggered by women; both display a deep distrust in feminine speech; both include what appear to be sly references to the identification of Jews and dogs; and both use the image of the animal to deliver messages on Jewish power, gender and class. And yet while the form of these messages appears on first sight to be similar, their content is almost diametrically opposed. The tale of the Rabbi-Werewolf envisions violence as a solution to the problem of exile: it is thanks to his savage attacks on Christians that the werewolf is hunted by the advisor; it is owing to his attack on the advisor that he is removed from the forest; and it is, finally, thanks to his icy threat to kill the king that he regains his human form. In this sense, the tale of the Rabbi-Werewolf belongs to a tradition of Yiddish fantasies of Jewish redemption through violence, much in the vein of the Yiddish Purim shpiln. ${ }^{57}$

The tale of the Princess and the Geese, on the other hand, offers a message of restraint, suggesting silence as the adequate course to redemption, and the proper response to persecution. The tale thus participates in a tradition of

56. Mayse bukh, IIor; MS. Opp. 7I4, fol. 9r. In the manuscript version he is well versed also in the tongues of animals.

57. For more on this active approach to persecution, see Rebekka Voß, 'Entangled Stories: The Red Jews in Pre-Modern Yiddish and German Apocalyptic Lore', AJS Review 36:I (20I2), pp. 20-28; 'Eschatological Avengers or Messianic Saviors? Violence and Physical Strength in the Vernacular Legend of the Red Jews', Early Modern Workshop: Resources in Jewish History Io: Jews and Violence (2013), pp. 70-7I; http://fordham.bepress.com/emw/emw2013/emw20I3/4 (accessed 27 October 2018). 
Old Yiddish works that seem to discourage active opposition to persecution. Such, for instance, is an intriguing tale which appears in the seventeenthcentury Mayse nissim by the shammash (beadle) of Worms, Yiftach Yosef Manzpach, known as Yuzpa Shammes. Yuzpa tells of a Jewish attempt to combat a well-poisoning libel by the use of violence. Faced with a certain death sentence, the persecuted Jews attack and kill their would-be persecutors. They then proceed to ravage the town - the men slaying the burghers, and the women setting fire to their homes. And yet, Yuzpa writes, 'no good came of this to the poor Jews (di arme yudn), nearly all of whom died'..$^{58}$ Some of the burghers, however, show the Jews mercy, and hide them in their homes, but a magical goose is summoned to expose the hiding survivors, and they are slaughtered by their neighbours. What remains of the community is subsequently delivered by the arrival in town of a learned Jew, well-versed in Latin and Christian theology (baki b'evn-glion). Presenting himself as a Christian priest, the man succeeds in casting doubts upon the goose's ability to accurately identify Jews, and those Jews who have remained in hiding are saved. ${ }^{59}$ Once again, in this Old Yiddish tale, animality (a goose!) serves as a symbol of persecution.

Contemporary readings have often viewed the tale as a Jewish revenge fantasy, or, in Lucia Raspe's phrasing, 'a powerful tale of Jewish resistance in the face of Christian violence ${ }^{60}$ And yet it seems significant that the violent acts of the Jews result only in further violence, indeed near-annihilation. In fact, it is only through deceit, disguise and to some extent diplomacy that the Jews are subsequently spared. Only through the workings of a Jew well-versed in Christian mores - in their language and religion - is the survival of the community ensured. ${ }^{61}$ Raspe argues that this Latin-speaking Jew is a subversive figure, meant to signify a Jew whose Christianity is a façade designed to assist his true co-religionists. However, knowledge of Latin was characteristic not only of converts, but also of other Jews, such as physicians or shtadlanim (intercessors), who often used their language skills

58. Yuzpa Shammash of Worms, Mayse nissim (I696; repr. Fürth, I766).

59. Yuzpa, Mayse nissim, I3r-I4v.

6o. Lucia Raspe, 'The Black Death in Jewish Sources: A Second Look at "Mayse Nissim"', Jewish Quarterly Review 94:3 (2004), pp. 473-4. See also Israel Yuval, " "They tell lies: you ate the man": Jewish Reactions to Ritual Murder Accusations', in Anna Sapir Abulafia (ed.), Religious Violence between Christians and Jews: Medieval Roots, Modern Perspectives (Basingstoke: Palgrave Macmillan, 2002), pp. $87-8$.

61. For a different view, see Raspe, 'The Black Death', pp. 477-9. 
and knowledge to serve as defenders of the Jews, interceding on behalf of their co-religionists. ${ }^{62}$ Moreover, in contrast to Raspe's argument that 'Only in Yuzpa's final sentence is the preacher revealed to be a pious Jew', the man is identified as Jewish from his very first appearance in the tale. Thus, upon his arrival in town, his Christian friend hides him in his house (fer borgt im bay zikh in zayn hoyz) - an act which would have been entirely unnecessary had the man not been identifiably Jewish. Later in the tale, when the guest communicates his plan to his Christian host, he explicitly states that he wishes to save the other Jews who remain in hiding (di andre yudn di nokh fer borgen zenen). ${ }^{63}$ For the reader, there is, then, no mistaking this man for anything but a Jew. However, the conduct of this Jew stands in direct contrast to that of the Rabbi-Werewolf, whose confrontational attitude and violent acts lead to salvation. Contrary to the werewolf, who threatens the king and refuses to communicate in any language but Hebrew, and to the community leaders (the parnassim) who attempt to save the community through violent resistance, the Jewish guest offers a solution not of active resistance but of passive concealment and disguise. It is only those Jews who remain in hiding that are saved, only those who keep silent or converse in the tongues of their persecutors that are delivered.

In its upholding of silence and concealment as the proper response to persecution and libel, the tale of the Magical Goose seems to agree with the tale of the Princess and the Geese regarding the proper response to persecution. Indeed, both tales adhere to Jewish understandings of violence as described by Israel Yuval: 'Jews in the Middle Ages were reluctant to use violence in acts of revenge, holding that revenge should be deferred until the messianic age. ${ }^{64}$ Yuval contrasts this approach to the purportedly more active approach exhibited by some early modern sources, but tales such as the Princess and the Geese and the Magical Goose point to the existence of a debate surrounding the issue of violence in early modern Ashkenaz. Indeed, these tales seem to participate in an entirely different reading of the book of

\footnotetext{
62. See François Guesnet, 'Die Politik der 'Fürsprache' - Vormoderne jüdische Interessenvertretung', in Dan Diner (ed.), Synchrone Welten: Zeitenräume jüdischer Geschichte (Göttingen: Vandenhoeck \& Ruprecht, 2005), pp. 67-92; John Efron, 'Interminably Maligned: The Conventional Lies About Jewish Doctors', in Elisheva Carlebach, John M. Efron and David M. Myers (eds), Jews History and Jewish Memory: Essays in Honor of Yosef Hayim Yerushalmi (Hanover and London: University Press of New England for Brandeis University Press, I998), p. 30r.

63. Yuzpa, Mayse nissim, I4r.

64. Yuval, 'They Tell Lies', p. 87.
} 
Esther than that of Purim shpiln, a reading that focuses not on confrontation but on concealment, not on revenge but on restraint.

\section{Natural and class hierarchy in Old Yiddish works}

The conservative nature of the tale of the Princess and the Geese is expressed not only in the narrator's negation of an active response to persecution, but also in what appears to be a stubborn rejection of any threat to the existing social order. In fact, the tale of the Princess and the Geese is a classic example of what Ruth Bottigheimer has termed 'a restoration tale', in which a noble protagonist is reduced to a deplorable social and/or economic position, and then returns to her original position. Bottigheimer contrasts this literary type with the 'rags to riches' type of narrative, which, she controversially argues, developed only during the early modern period. While Bottigheimer's study has been widely criticized for its periodization of printed tales based on oral traditions, the distinction between the 'rise tale' and the 'restoration tale' is useful for our purposes, as it affords a view into the social commentary made by the tale of the Princess and the Geese. ${ }^{65}$ Unlike the 'rise tale,' which is in essence a fantasy of upward mobility, the restoration tale views such mobility as necessarily negative, whether tragic as in case of Esther and her seven brothers, or preposterous as in other contemporaneous Yiddish tales. ${ }^{66}$

The problem of class mobility is treated in the tale of the Princess and the Geese, once again, through the image of animals. Indeed, the beginning of the reversed narrative, in which the borders between man and beast are re-established, is triggered, of all things, by an animal act. It is the lioness's recognition of two baby princes' nobility that initiates the restorative process, which puts to rest the constant slippage of species that characterizes the tale.

65. For Bottigheimer's thesis and the debate surrounding it, see Ruth B. Bottigheimer, Fairy Godfather: Straparola, Venice, and the Fairy Tale Tradition (Philadelphia PA: Universit of Pennsylvania Press, 2002); Jan M. Ziolkowski, 'Straparola and the Fairy Tale: Between Literary and Oral Traditions', Journal of American Folklore I23 (20I0), pp. 377-90; Dan Ben-Amos, 'Straparola: The Revolution That Was Not', Journal of American Folklore I23 (2010), pp. 426-46. Jeremy Dauber offers a fascinating reading of the famous 'Mayse fun Vorms' as an early Yiddish rise story, which, he argues, offers 'nuanced challenges to social order while remaining within that order.' Dauber, Demon's Bedroom, p. I6I.

66. For an example of the latter, see Anon., Eyln shpigl (Prague, I735), [29]-[30] (n.pag.). For a discussion of the conservative nature of this adaptation, see Idelson-Shein, 'Meditations', pp. 28-9. There exists also another Yiddish version of this tale which develops into a rise tale; see Elchanan Kirkhhan, Simchat ha-nefesh (1707; repr. Sulzbach, I7I7), 36v-37r. 
It seems hardly coincidental that the particular animal chosen to restore order is the lion. Long imagined as the leader - indeed, the king - of the animal world, the image of the lion endows animals with a comforting kind of class hierarchy, corresponding to that of humans. Such usage of the image of the lion is ubiquitous in early modern literature. ${ }^{67}$ In Elye Bokher's sixteenthcentury Bovo d'Antona, for instance, the lion similarly appears as an animal with a distinct respect for hierarchy and class. In the scene in question, the brave prince Bovo's companion, Pelukan - himself a dog-headed man - is killed by two lions. The lions, however, spare the life of Bovo's wife, the princess Drusiana and her two sons, since, as the author explains, 'a lion does not harm noble blood' (kayn leyb tut nisht keynem blut dem eydln) ${ }^{68}$ Other early modern Yiddish works which feature lions or lionesses who yield to human royalty are Kaizer Oktavian (c.1580) and Ayn sheyne geshikhte fun Daitsh land (c.1750). ${ }^{69}$

Embedded in these scenes is the notion that lineage is inscribed somehow so deep that it transcends even special boundaries. ${ }^{70}$ Indeed, in all the confusion of species and bodies that occurs throughout the tale of the Princess and the Geese, class emerges as the one stable category, the only reliable organizing principle of the world. It is the lioness's recognition of the children's nobility that saves them from being eaten; it is the king's recognition of Esther's nobility that saves her from the forest; and it is, indeed, the outrageousness of regicide that saves Esther from being burned at the stake. Having regained their human form, the brothers hear of the upcoming execution, and, not knowing that their sister is involved, they decide to attend, as 'it must be strange [zeltsamz] to see a queen being burned at the stake'. ${ }^{71}$

Here, again, the politics of the tale of the Princess and the Geese contrast sharply with those of the Purim shpiln, which, as Frakes explains, 'sometimes subtly, sometimes savagely ironized the instances of authority in the Christian

67. See, e.g., Shakespeare, Henry IV, 2.4.

68. Bovo d'Antona by Elye Bokher. A Yiddish Romance, Critical edition, ed. Claudia Rosenzweig (Leiden: Brill, 20I6), p. 403.

69. Ayn sheyne geshikhte fun Daitshland (n.p., c.I750), [5]; MS Munich, Cod.Hebr.Ioo, fols I-66, Bavarian State Library; http://daten.digitale-sammlungen.de/ db/ooo3/bsbooo36332/images/index. html?id $=00036332 \&$ nativeno $=\mathrm{I}$. The tale of Kayser Okatavian bears several striking similarities to that of the Princess and the Geese, which need to be studied in detail.

70. For a different but related theme in old Yiddish literature, see Oren Roman, 'A Man Fighting a Lion: A Christian “Theme" in Yiddish Epics', Interfaces 5 (2018), pp. 90-I Iо.

7I. Ayn sheyn mayse, 5v. 
community'. ${ }^{72}$ It also stands in opposition once again to the tale of the Rabbi-Werewolf, which, as noted above, shows a remarkable disdain for class hierarchy. Perhaps it is not surprising, then, that the werewolf is presented in this latter tale as stronger than a lion - a testimony to the rabbi's radical rejection of any worldly authority, including that of lion over wolf, man over beast, Christian over Jew.

\section{Conclusion}

There is an old proverb in Yiddish that says a hen that crows like a cock should be slaughtered immediately (a hindl vos kreyet darf man teykhf shochtn). Equating breaches of gender roles with breaches of nature, the saying delivers a stark message about the naturalness of social hierarchies. At the same time, it powerfully asserts who it is that has the right to be heard, and when. ${ }^{73}$ This kind of usage of animality as a rhetorical foil for discussing questions of hierarchy, gender, speech and proper conduct is, as we have seen, characteristic of Old Yiddish literature. Indeed, it is perhaps only fitting that Yiddish authors were to be so troubled precisely by these questions - after all, early modern Yiddish literature was delegated to a specific place within the Jewish literary world, a place densely populated by the masses of Jews who were unable to read loshn-koydesh. And yet, like the animals of the two transformation tales surveyed above, Yiddish literature consistently threatened to seep into new territories. The division of labour between Yiddish and Hebrew was thus strictly supervised, and works that were suspected of straying from their proper course - such as Yiddish prayer books or Halakhic works - were promptly banned. ${ }^{74}$ These works - hens that crowed like cocks - were, indeed, slaughtered immediately.

Of course, Yiddish literature held a close and complex relationship not only with Hebrew literature, but also with non-Jewish (and particularly German) literature. This relationship was no less explosive, and Yiddish

72. Frakes, Emergence of Yiddish, p. Io9.

73. The saying does not originate in Yiddish. Ironically, the Talmud views it as idolatrous. See bShab. 67b. For a history of the saying in its Hebrew context, see Stephen D. Benin, 'A Hen Crowing like a Cock: "Popular Religion" and Jewish Law', Journal of Jewish Thought and Philosophy 8 (I999), pp. 270-8I. For a discussion of the saying in the context of another Old Yiddish tale, see Dauber, Demon's Bedroom, pp. 203-4.

74. See Berger, 'Third Space', p. 78; Shmeruk, Sifrut Yiddish, pp. I3-I8. 
translations which appeared too close to their non-Jewish sources were frowned upon. In fact, no few Yiddish works were created precisely to serve as alternatives to such seemingly mindless transliterations of German tales. ${ }^{75}$ The two transformation tales discussed here - the Princess and the Geese and the Rabbi-Werewolf - were, I would suggest, meant to serve precisely such a purpose. They are both heavily Judaized adaptations of non-Jewish tales, which import non-Jewish ideas and adventures into the Jewish literary sphere while at the same time attempting to keep the foreign aspect of their tales at bay. They thus aim to serve as gatekeepers of the Yiddish literary world. And yet their own unstable position, patrolling the border between Hebrew and German, Jewish and Christian, results in a plurality of voices, which threatens to tear down the neat divisions to which these works aspire. In a sense, these tales share the same problem as their protagonists - that of two, or even three, separate bodies/corpora inhabiting one space.

In dealing with this ambivalence, the two tales suggest solutions which are almost diametrically opposed. Rejecting exile and calling for active deliverance, the Rabbi-Werewolf insists on Hebrew and violence as ways to bring about deliverance and put an end to the translation/transformation conundrum. The tale of the Princess and the Geese, on the other hand, takes a passive, seemingly feminine approach, suggesting that the ambivalence of exile, of Yiddish literature itself, can only be resolved through compliance. Deliverance depends on strict adherence to social, religious and literary divisions. For all their differences, the two tales participate in the same painful debate about exile and deliverance, translation and transformation - a debate which would only have been possible in Yiddish.

75. See Chava Turniansky, 'Yiddish and the Transmission of Knowledge in Early Modern Europe', Jewish Studies Quarterly I5:I (2008), p. I6; Paucker, 'Yiddish Versions', pp. I5-I6. 